\title{
EchoGéo
}

$53 \mid 2020$

Dénominations plurielles. Quand les noms de lieux se concurrencent

\section{Naming the sites of the opioid crisis in Boston: a political issue}

\section{Elsa Vivant}

\section{OpenEdition}

\section{Journals}

Electronic version

URL: https://journals.openedition.org/echogeo/21369

DOI: 10.4000/echogeo.21369

ISSN: 1963-1197

This article is a translation of:

Nommer les lieux de la crise des opioïdes à Boston : un enjeu politique - URL : https://

journals.openedition.org/echogeo/20001 [fr]

\section{Publisher}

Pôle de recherche pour l'organisation et la diffusion de l'information géographique (CNRS UMR 8586)

\section{Electronic reference}

Elsa Vivant, "Naming the sites of the opioid crisis in Boston: a political issue", EchoGéo [Online], 53| 2020, Online since 30 April 2021, connection on 07 December 2022. URL: http:// journals.openedition.org/echogeo/21369 ; DOI: https://doi.org/10.4000/echogeo.21369

This text was automatically generated on 10 August 2021

\section{(c) $(1)(9)$}

Creative Commons - Attribution-NonCommercial-NoDerivatives 4.0 International - CC BY-NC-ND 4.0 https://creativecommons.org/licenses/by-nc-nd/4.0/ 


\title{
Naming the sites of the opioid crisis in Boston: a political issue
}

\author{
Elsa Vivant
}

In memorium Aubri Ester

\section{Naming the sites of the opioid crisis in Boston: a political issue}

On 14 October 2014, the Mayor of Boston decided to block access to Long Island Bridge to all forms of traffic. Support facilities for the city's poorest, many of whom had been residents of the island for a long time, thus had only a single day to close and move out. Within a few hours, the emergency homeless shelter and addiction treatment centres had to relocate their activities elsewhere in the city area, mostly in precarious conditions. This unprepared emergency relocation contributed to rendering the living conditions of the homeless even more precarious, leaving many unable to find shelter. It was one of the contributing factors leading to the emergence of an open drug scene around the junction of two major thoroughfares (Massachusetts Avenue and Melnea Cass Boulevard) in an interface area between three neighbourhoods with contrasting uses and dynamics: an area of light industry and storage (Newmarket), a black and Latino working-class neighbourhood (Dudley-Roxbury), and a gentrified neighbourhood (South End). The mayor's decision came at a time when the opioid crisis had become a public and political issue with extensive media coverage ${ }^{1}$. The crisis, which had been latent since the late 1990s, erupted with the introduction of a powerful synthetic opioid (Fentanyl) on the underground market, leading to a dramatic increase in overdose mortality².

2 The open scene drew the attention of the media and public authorities as addiction and overdose issues were brought to the fore, along with the conflicts it generated around the use of public space. It bears a variety of names, each of which relates to different representations of the problem and to local geopolitical stakes. Examining this scene through the lens of its names is particularly heuristic. It allows us to unravel the 
complexity of this health crisis, its political stakes, and the shifts it is bringing about in drug policy. As several authors (Giraut and Houssay-Holzschuch 2008; Rose-Redwood and Alderman 2011) have pointed out, the act of naming a place is political, and debates on toponymy are opportunities to analyse the social and political - and, in this case, health - dynamics at play in a space. In this article, plurality in names will be used as a heuristic tool in understanding the opioid crisis and its effects on the social representations of drug users. Debates on the ways of naming not only places but also treatments or drug users, shed light on the emergence of new care practices and political representations of drugs and their users.

The article ${ }^{3}$ is based on an in-depth survey conducted between September 2018 and June 2019, which involved 70 interviews $^{4}$ and observations in as many meetings of various types ${ }^{5}$. While the article is structured around the three most commonly used toponyms, other denominations will come into play at times, depending on the different scales being discussed (from single buildings to entire neighbourhoods). Behind its apparent neutrality (Rose-Redwood and Alderman 2011), the reference to the open scene's postal address, Mass \& Cass, is actually a reference to the urban, colonial and racial history of the city and of prohibition. Two visions of addiction and care compete behind other names. The many drug user care, support, or management services located in the area (the county jail and its probation services, methadone clinics, long-term and emergency shelters, daytime support facilities) have led critics to dub it Methadone Mile. Caregivers, on the other hand, prefer to call it Recovery Road, a reference to the hope that these services' presence could inspire.

\section{Mass \& Cass: behind the official toponymy, an underlying colonial heritage}

4 The official way to denote the open scene is to refer to its geographical location through its address, at the intersection of two major thoroughfares: Massachusetts Avenue and Melnea Cass Boulevard, often abbreviated as Mass \& Cass. This official toponymy refers to the darkest pages of American history: colonization and racial segregation. Massachusetts Avenue runs through the metropolitan area from Arlington to Dorchester and along MIT and Harvard's campuses in Cambridge, follows the axis of gentrification from South Bay to South End, and finally crosses into the industrial areas of Newmarket. Most importantly, Massachusetts is the name of the indigenous people who lived on these lands before Europeans arrived and were decimated in the early years of colonization. Only a few dozen of their descendants have survived and are currently still fighting for their rights. Melnea Cass Boulevard was built in 1981 on land set aside for a highway construction project, which was contested by local residents and abandoned in 1972 (Miller, 2018). In the absence of a highway, the boulevard, which is divided into two three-lane sections and interspersed with traffic lights, constitutes an urban divide between downtown and Roxbury. It is named after Melnea Cass (1896-1978), an African American activist for the political, social and economic rights of women in her community of the Dudley-Roxbury neighbourhood, who was highly active in the struggles for school desegregation (busing) that led to violent protests in Boston (King 1981, O'Connor 2001). A testimony to the political issues surrounding toponymy is the renaming, in 2019, of a square originally named after former governor, founding member of the Massachusetts Bay Colony and, as 
proponents of renaming the square pointed out, slave owner Thomas Dudley. The current name is Nubian Square, in recognition of the African American population's contributions in the neighbourhood (MacQuarrie 2019, Greenberg 2019). This decision, however, came at a time when the neighbourhood was already on the road to gentrification, and thus might be little more than a memorial to the presence of a population in the process of being evicted ${ }^{6}$.

Residents of the black district of Dudley-Roxbury contest this way of referring to the place by its address. They argue that, by producing a new spatiality and inventing an imagined territory that did not exist a few years earlier, it conceals the real impact of the crisis on their district and steers attention and municipal action away from it. In public meetings and in interviews, the residents of Roxbury express their resentment at the fact that their neighbourhood is once again affected by a drug problem and that the authorities, in their view, are turning a blind eye to it. They mainly express anger about the presence of used syringes in a public park (Clifford Park) and in the courtyard of Orchard Garden School, which had itself been built as part of the redevelopment of the Orchard Park area after it had been one of the city's main drug scenes in the 1980s. In 2017, teachers and parents formed a pressure group that meets twice a month to define their strategy and demands, and to make them known on social media. They are concerned about the effects of the daily sight of people injecting drugs, or behaving in ways they deem deviant, on their children's mental health. They have organized demonstrations, in which schoolchildren were also present, to demand the installation of fences around the courtyard, an increase in police presence, and daily cleaning operations in the surroundings. A ferocious spokesperson for their cause is football coach Domingos DaRosa, who has run in municipal elections twice to put the issue of drug use in public spaces and the dangers of used syringes onto the political and media agenda. On several occasions at public meetings he has emptied boxes of syringes collected at Clifford Park, where his team trains. Other residents report the syringes to the city's services via an online platform, photograph them, publish their photographs on social media, count them, and map them (Bearnot et al, 2018). 


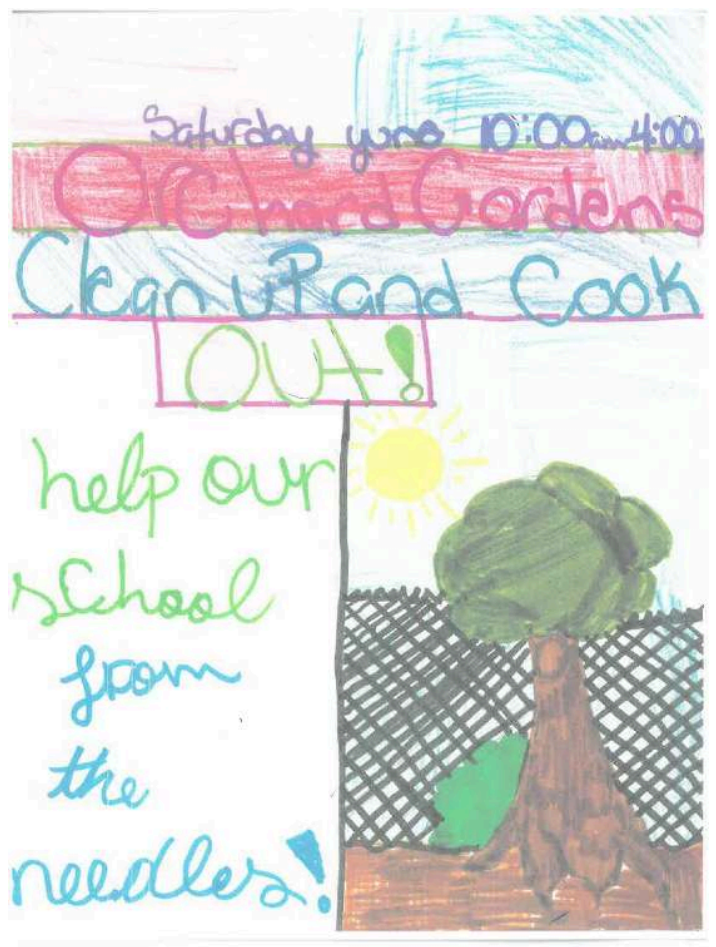

Source: created by an anonymous pupil of Orchard Garden School, spring 2019

6 While public meetings are an opportunity to highlight tensions and resentment between residents of Roxbury and of South End, they are also a fine opportunity to raise awareness of possible alliances between the two neighbourhoods to bring the residents' point of view to the city council's attention. The chairman of a South End neighbourhood association argues that, despite the social and racial differences and regardless of relationships of domination, white gentrifiers and black residents need to work together to make the city council face evidence of the extent of the problem. Roxbury residents, on the contrary, repeatedly express their feeling of not being listened to due to their position as poor, immigrant and racialized people. In their view, any alliance with South End residents would entail a denial of the reality of economic and political disparities. They refuse to see their neighbourhood cast once again as the area where drug use can be trivialized. Their complaints also touch on a sense of injustice due to the differences in the way the current crisis is being addressed by comparison with the forms that the war on drugs previously took and the effects it had when targeting their neighbourhood. Their feeling is corroborated by Netherland and Hansen's analysis (2016), which shows how media coverage of the current crisis produces a relatively benevolent representation of white opioid users, quite opposite the stigmatizing ways in which black crack users were depicted (Alexander 2010). 


\section{Methadone Mile: an informal toponymy of stigmatization}

7 When Long Island Bridge was shut, this was the area where a building was soon converted into a men's shelter, another shelter doubled its capacity and, concurrently but independently, a second private methadone clinic was set up. These came as additions to other services aimed at or taken up by marginalized populations and drug users: the hospital and its addictology service, the needle exchange service, the city's homeless clinic, two detoxification clinics, a private methadone clinic, probation services, and the county jail. This concentration of services is part of what makes the crisis so visible, or rather of what draws attention to its most visible aspect: the part of it that takes place in the public space and might distract from other forms of addiction. Residents identify it as the cause for the increase of disturbances and conflicts around the use of public space. Methadone clinics are the main targets of criticism and discontent, hence the area's disparaging nickname Methadone Mile which, among its denominations, is by far the most commonly used in the press, in ordinary conversations, and in public debates ${ }^{7}$.

8 To explain the stigmatization of this name, we need to bear in mind that methadone treatments have aroused suspicion ever since they were first tried out in New York, in the late 1960s. They were deployed under the Nixon administration, at the same time as users were criminalized and the first war on drug programmes were launched. The purpose of introducing these treatments was to reduce drug-related urban crime, to anticipate the need to provide care for veterans returning from the Vietnam War, and to address the growing use of heroin among young people from the suburban (white) middle classes (White 1998, Musto 1999, Schneider 2011).

9 In spite of its efficacy, which medical professionals have consistently upheld, the very principle of drug treatment for addiction remains controversial in the United States, where the abstinence paradigm and the addicts anonymous model prevail in the care offer. Critics see methadone merely as a drug like any other, which traps individuals in chronic dependence while failing to address the psychological causes and social context of consumption. Another line of criticism focuses on methadone clinics' lack of professionalism and their greed in a poorly regulated market where discrimination in access to care persists to this day (White 1998). Media coverage of certain clinics' abusive practices (failure to follow up on patients, lack of control over the substances prescribed, overpricing) has contributed to giving this mode of treatment a bad reputation (Platt et al., 1998). The treatment protocol requires users to go to a specialized clinic every day to take their dose in front of a health professional. Only later can they take a few days' worth of treatment home. This is to ensure that the patients visit the clinic daily. In this case, residents estimated the number of these patients at over 1300. These (un-sourced) counts are at the centre of their arguments and fuel their concerns about the installation of other healthcare facilities. Due to health and urban planning regulations and the constraints they impose on methadone treatments and clinics, these clinics are often located in areas that are treated as second rate. Criticism levelled at them thus redefines heroin-induced urban decline, with clinics being accused of attracting drug dealers by creating a captive customer base (Schneider 2011). 
10 While the proximity of hospitals and social services has always attracted marginalized populations to South End, residents have noticed a change in their numbers and behaviour in public spaces since 2014. They attribute this to an accentuation of the aggregation effect that followed the relocation of services from Long Island. As good neighbours (Tissot 2015), they wanted to inform themselves and sought comprehensive solutions to the problem of drug use in the public space. Neighbourhood associations' representatives took part in work meetings with city authorities and hospital management staff to understand the issue and its causes, and to identify solutions. In order to resolve conflicts over the use of public space and to restore the quality of their living environment, they proposed a better geographical distribution of care facilities and more flexible treatment methods. This was consistent with calls that Boston city councillors made to other local authorities to take responsibility for what they considered to be their share of this burden. From their point of view, the lack of care services in other cities and the way other communities had forsaken their drug users explained the scale the crisis reached in their city.

Other names attract attention, such as the New Market Association's use of the term Ground Zero (in reference to the site of the 11 September 2001 attacks) to emphasize the scope of the crisis the district faces. This business owners' association also put forth a proposition to create a Business Improvement District, in which the management of public space and of its uses would be privatized, to tackle an issue the city seemed unable to resolve on its own. To do so, the association would need to obtain the City's authorization and to convince a majority of business owners in the area to pay a land surcharge for the BID's management, which would provide private security and cleaning services. This intervention would focus on the perimeter of the industrial zone and its immediate surroundings, thus excluding the residential districts of Roxbury and South End ${ }^{8}$. This area of privatized management of public space would come as an addition to the districts that had already been set up around university and hospital properties. Private police would operate there, in addition to city and state police. Homelessness activists alleged that these private security services exercised institutional violence through discriminatory harassment (eviction of homeless people, access restrictions, etc.). These various perimeters of public space management reinforced the border effects produced by urban divides and by the different administrative, electoral, political and police district boundaries, which do not overlap. 
Illustration 2 - The open scene: a concentration of services for drug users at the interface of three neighbourhoods

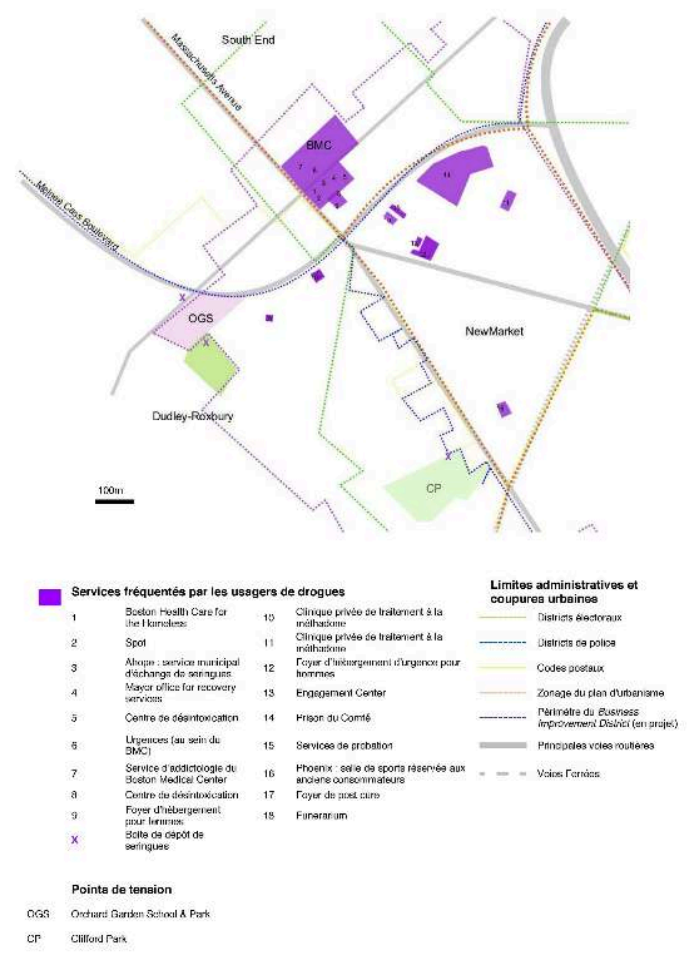

Source: Elsa Vivant

To describe the situation, several respondents referred to the third season of the series The Wire, in which a police officer responds to hierarchical pressure to obtain a reduction in crime statistics by taking the initiative to tolerate drug use within a delineated fraction of his district. He then forcefully urges the neighbourhood's drug dealers to take their business exclusively to this zone, a small residential street lined with abandoned houses slated for demolition. While the experience initially arouses more suspicion than enthusiasm among police officers and drug dealers alike, it turns out to be promising. Corners are deserted and conflict around them fades, crime rates fall, and users flock to this free zone nicknamed Hamsterdam. But pseudo-legalization also shows its limits. On the one hand, in the absence of police control, there is no longer any need to have anyone on the lookout, and the children who used to fill these positions are left to themselves; on the other hand, the concentration of the most problematic forms of consumption in a small area makes them more visible. Respondents cited this work of fiction to express their fears of seeing drug use normalized. This concern was particularly salient in the comments of two African American respondents in their forties, whose father and other family members had been drug users. In addition to the legalization of a street scene, this season of the series stages another process: that of an evolution in police practices, driven by officers who are aware of the limits and dead ends of policies they implement in the face of a situation that is beyond their control. In the real world, some police officers, faced with an overdose mortality that they attribute to a product of unparalleled dangerousness and over which they have little control, are currently changing their practices towards more comprehensive approaches. The implications and limits of these approaches warrant academic attention (Green et al., 2013). 
Illustration 3 - Welcome sign at the car wash located at the intersection of Melnea Cass and Mass Av.

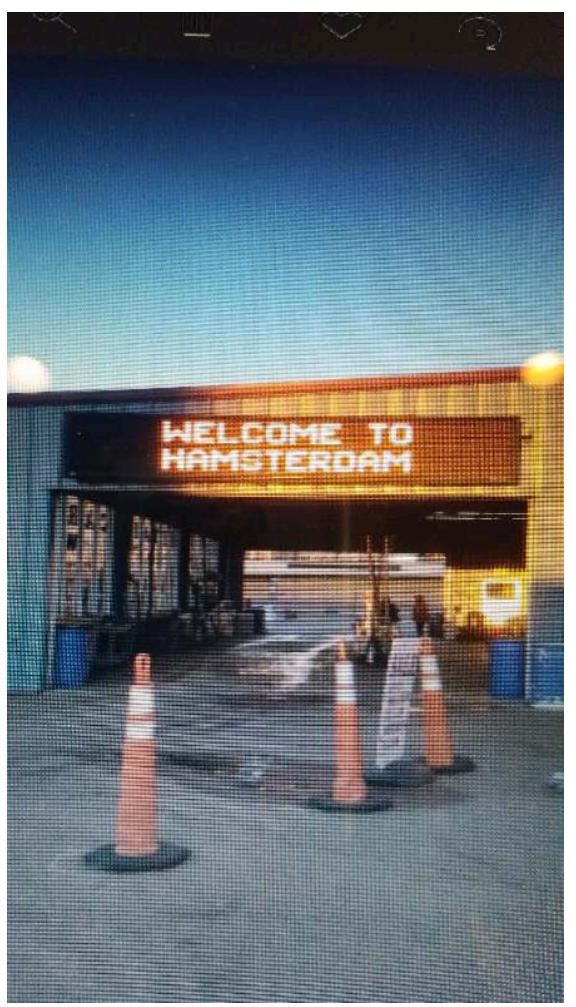

Source: unknown 10

Rather than Amsterdam, the imaginary experiment in The Wire is reminiscent of the city of Zurich's attempt, between 1987 and 1992, at geographically containing the issues and disturbances associated with drug use. Having taken note of how ineffective the police's strategy of dispersing drug users was, the city council decided to tolerate heroin use in a park near the main railway station (Platzspitz), where access to care and harm reduction practices (such as the distribution of syringes) were tried out to tackle the HIV epidemic (Grob 1993, Lalande 2018). The experiment had to be terminated after a few years, as health and safety conditions had spiralled out of control. The park was nicknamed Needle Park, following the same logic of toponymic stigmatization that led residents of Boston's open drug scene area to call their social media group A Needle in the Park, after Jerry Schatzberg's 1971 film Panic in Needle Park, starring Al Pacino. As the park experiment was terminated in Zurich, permanent prevention and medical services and harm reduction facilities for drug users were established, including drug consumption rooms, which were initiated in Bern in 1986 (Jauffret-Roustide, 2016) and contributed to the emergence of a different approach to recovery.

\section{Recovery Road: Requalifying the problem and considering solutions}

14 To avoid the stigmatized image of Methadone Mile, doctors and harm reduction professionals prefer to use the term Recovery Road as a way of emphasizing endeavours to support consumers on the road to recovery in various services ${ }^{11}$. The term recovery is also used to describe areas experiencing a revival of activity and attractiveness after a 
period of decline. Its use is polysemic here, as the Newmarket district, a pericentral industrial zone, is identified in urban planning documents as a territory of strategic stakes, one that is itself undergoing recovery. The relocation to the area of several services dedicated to addiction care and/or homelessness has resulted in an increase in the use of public spaces by marginalized populations. In 2017, in response to requests from residents and local businesses to reduce disturbances and risks associated with behaviour deemed to be deviant, and with a humanitarian aim to provide shelter, the city converted a marquee previously used as storage space to create an Engagement Centre. This centre is heated in winter and air-conditioned in summer, it is open 12 hours a day, 7 days a week, and welcomes people unconditionally - that is, with no questions asked, no identity or weapons checks and no obligation to be sober. There, users can rest, meet social workers, access toilets, meet their friends and spouses, ${ }^{12}$ charge their phones, and so on. The site's designers had to work with many constraints and requirements as the place is only a tent, located in a small street in an industrial zone, between an emergency shelter and a jail, both of which have requested the installation of barriers to prevent intrusion. They sought an emergency solution, in the face of residents' hostility and with limited means, to make it as welcoming as possible using furniture, painting on the floor to delimit different spaces, potted plants, a library, free-access computers, and a drinks and snacks distribution counter.

Illustration 4 - The entrance to the Engagement Center

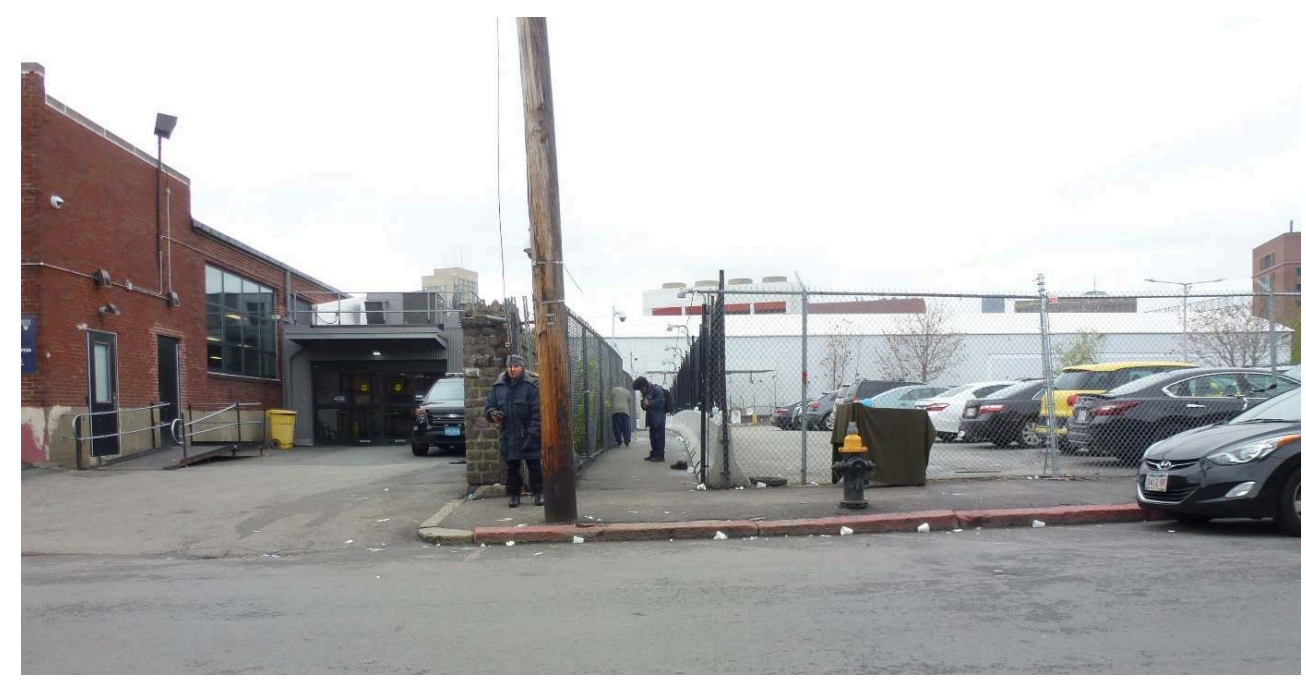

A fenced corridor monitored by three cameras has been created to delimit access between the entrance to the shelter (left) and the Sheriff's Department and the county jail's car park (right). A few wooden tables in front of the marquee entrance form a terrace, around which portable toilets have been installed.

Source: Elsa Vivant

This facility is supported by the business owners' association, which has overcome its initial reluctance and now deems the facility to have positive effects on the use of public space. Yet it still generates controversy. Some residents consider that it contributes to the crystallization of conflicts around the use of public space in the sector, with drug sales and consumption taking place openly in its front court, before the police's eyes. This fuels another line of criticism, focused on the use of taxpayers' money ${ }^{13}$. While this setup was designed as a temporary experiment in response to the 
emergency, at the time of the survey municipal services were considering making it permanent.

In 2016, faced with the huge increase of overdoses in the area, the city's homeless care centre also converted a small meeting room into a medicalized rest area where users could go immediately after consuming drugs. It was based on the same principle of unconditional low-threshold access as the Engagement Centre. In a calm and softly lit atmosphere, users are under medical supervision and nurses can intervene in the event of an overdose. This service, called Spot (Supportive Place for Observation and Treatment), is presented as a success in terms of reducing overdose mortality, mitigating drug use in public spaces, providing access to care, and obtaining acceptance from residents. The State of Massachusetts is drawing from it to define its overdose reduction policy.

For harm reduction actors and activists, the Engagement Center and Spot are only a stopgap measure. They advocate for the creation of low-risk consumption rooms to curb infection rates, reduce overdose risks, and contribute towards de-stigmatizing users by providing them with a space adapted to their needs. Such spaces have existed for several decades in some European countries ${ }^{14}$ and are currently prohibited in the United States. In recent years, activists have been organizing in several American cities to convince policy makers to change legislation in order to make it possible to create safer consumption rooms (Lupick 2017). In Boston, the Safe Injection Facilities Massachusetts Now! coalition was launched in 2016 and soon caught some law-makers' attention. A bill was tabled in 2017, to no avail, but then in 2018 the governor set up a commission which concluded its work by recommending that consumption rooms be experimented with. At the time of writing this article, lobbying is underway to introduce a new bill to the legislature elected in 2020. Yet numerous hurdles remain, and while an increasing number of city councillors are convinced of this proposal's merits $^{15}$, the governor is hampering legislative progress. The US Attorney for Massachusetts has threatened to arrest anyone working at such a site, and residents remain suspicious at best about the effect such a facility might have on the use of public space in their neighbourhood.

Here again, the question of naming is crucial. Detractors see these places as shooting galleries (which conveys the degrading image of injecting drugs in insalubrious conditions) or heroin dens (in reference to opium dens). To put these concerns to rest, some people suggested calling these sites safe consumption spaces rather than safe injection facilities (a term the activist coalition had settled for at first), so as to conceal the stigmatizing image of syringes while also including drug users who do not inject (and especially crack smokers). Others suggested that they be called overdose prevention sites or harm reduction sites, so as not to explicitly convey the idea of drug use, and to focus instead on prevention as the end goal (to avoid overdoses and reduce risks), which could lead to various types of action. The idea was to use language to upend the dominant discourse that construes addiction as a moral failure, stigmatizes individuals, and places the blame on them and on those around them (families, friends, neighbours, community), and instead to present addiction disorders as a disease. Presenting these systems as the first steps towards recovery and the point of entry into the treatment process was a way of convincing the most reluctant people by adopting a recovery management approach (Stuart 2014) to guide drug users on the right path, that of care and, perhaps one day, abstinence. Locating these services in a space called road rather 
than mile reinforced the idea that recovery was a long and uncertain process, thus echoing to the expression on the road to recovery.

\section{Conclusion: Naming as an instrument for changing practices and representations}

The various names given to the open drug scene carry several lines of claims with them and stand as reminders of the importance of the choice of words when describing a situation and articulating an issue. The inhabitants of the poor African American neighbourhood of Roxbury decry the use of addresses (Mass \& Cass) as a toponym, claiming that it minimizes the impact of the crisis on their neighbourhood and obscures socio-spatial relations of domination. To deal with the feeling of injustice and abandonment, they organized to draw the city council's attention and action to deterioration in the quality of their living environment, and especially drug use in public spaces and the traces it leaves in the form of syringes. By emphasizing the most controversial aspect of the provision of care by the name Methadone Mile, residents of the open scene area called on other communities to take their share of the problem into their own hands. Health professionals, on the other hand, uphold the hopes that new harm reduction practices, which are still in a legal grey area, are raising when it comes to limiting the effects of drug consumption on society and users' health, lives, and deaths. They thus defend the use of the name Recovery Road, which could herald more comprehensive social and urban rehabilitation.

There are political stakes in the denomination of more than just places. Through changes in vocabulary, drug user activists are calling for a change in the way drugs and their uses are viewed. For example, the (increasingly current) terms substance use disorder and people who use drugs serve as reminders that many occasional users do not have a dependency problem. Yet the voices of those most directly concerned, the users, are still seldom heard in public discussions, even though they have recently formed a collective (Boston Users Union), which is active on social media and has been invited to take part in discussions on health policy design.

Finally, although there is a slight shift towards more compassionate approaches in the naming of people and places, vexatious attitudes towards homeless people and drug users remain frequent. In the summer of 2019, following an upsurge of public disorder, the city of Boston conducted a police operation called "clean sweep", in which homeless people's belongings were destroyed and several arrests were made. This vocabulary and process are reminiscent of the darkest hours of the war on drugs and of the banishment logics governing the lives of homeless people (Beckett and Herbert, 2009). Subsequently, the municipality deployed an action plan to improve the quality of life, which it called Mass \& Cass 2.0, in reference to the idea of the web 2.0, to convey the idea of a more participatory renewal of the definition of policies for the management of public space (the question being who, of residents or drug users, is invited to participate). However, residents demand more than police intervention; they also consider changes in the supply of care, its distribution (to fragment rather than concentrate it) and its therapeutic modalities. They also support the City of Boston's project to rebuild the Long Island Bridge and reopen addiction care services on the island. In other words, to move the problem out of sight - once again. 


\section{BIBLIOGRAPHY}

Ahrnsbrak, R., Bose, J., Hedden, S., Lipari, R. and Park-Lee, E. (2017) Key Substance Use and Mental Health Indicators in the United States: Results from the 2016 National Survey on Drug Use and Health, No. SMA 17-5044, NSDUH Series H-52. Rockville, MD: Substance Abuse and Mental Health Services Administration.

Alexander, M. (2010), The New Jim Crow: Mass Incarceration in the Age of Colorblindness, New York, The New Press

Bearnot, B., Rodriguez, J., Pearson, J. (2018) Crowdsourcing the Opioid Epidemic. Public Health Post, September 6, 2018. https://www.publichealthpost.org/viewpoints/crowdsourcing-theopioid-epidemic/.

Beckett, K. Herbert, S. (2009) Banished. The New Social Control in Urban America Oxford University Press, Oxford.

City of Boston (2017) Imagine Boston 2030. City of Boston, Boston.

Clark, C. (2017) The Recovery Revolution. The Battle Over Addiction Treatment in the United States. Columbia University Press, New York.

Fitzgerald, B., (2017) Supervised Injection Facilities: Harm or Harm Reduction? Public Health Post, 16 July 2017. https://www.publichealthpost.org/essays/we-can-do-better/.

Giraut, F., Houssay-Holzschuch, M. \& Guyot, S. (2008) Au nom des territoires : Enjeux géographiques de la toponymie. L'Espace géographique, 37(2), 97-105. doi:10.3917/eg.372.0097

Green, T., Zaller, N., Palacios, W., Bowman, S., Ray, M., Heimer, R. and Case, P. (2013) Law enforcement attitudes toward overdose prevention and response. Drug and Alcohol Dependence $113,677-84$.

Greenberg, Z. (2019) ‘A new day’: Dudley Square is renamed Nubian Square. Boston Globe. 19 December. Boston.

Grob, P. J. (1993) The needle park in Zürich. The story and the lessons to be learned. European Journal on Criminal Policy and Research 1.2, 48-60.

Jauffret-Roustide, M. (2016) Les salles de consommation à moindre risque. Apprendre à vivre avec les drogues. Esprit 11, 115-23.

King, M. (1981) Chain of Change. Struggles for Black Community Development. South End Press, Boston.

Lupick, T. (2017) Fighting for Space. How a group of drug users transformed one city's struggle with addiction. Arsenal Pulp Press. Vancouver.

MacQuarrie, B. (2019) Dudley Square: at the intersection of Colonial history, African heritage. Boston Globe. 18 December. Boston.

Massachusetts Department of Public Health (2016) Chapter 55. An assessment of Opioid-Related Deaths in Massachusetts (2013-14). Boston: The Commonwealth of Massachusetts.

Meier, B. (2003) Pain Killer. A ‘Wonder' Drug's Trail of Addiction and Death. Rodale, New York. Meyers, T. (2013) The Clinic and Elsewhere: Addiction, Adolescents, and the Afterlife of Therapy, Seattle, University of Washington Press 
Miller, M. B. ed. (2018) Boston's Banner Years: 1965-2015. A Saga of Black Success. Archway Publishing, Bloomington, In.

Musto, D. F. (1999) The American Disease. Origins of Narcotic Control (3rd edition). Oxford University Press, New York.

Netherland, J. and Hansen, H. (2016) The War on Drugs that Wasn't: Wasted Whiteness, 'Dirty Doctors', and Race in Media Coverage of Prescription Opioid Misuse. Culture, Medicine and Psychiatry 40.4, 664-86.

O'Connor, T. (2001) The Hub. Boston Past and Present. Northeastern University Press, Boston.

Platt, J., Widman, M., Lidz, V. and Marlowe, D. (1998) Methadone Maintenance Treatment: Its Development and Effectiveness after 30 years. In Inciardi, J. and L. Harrison (eds), Heroin in the Age of Crack-Cocaine. Sage, Thousand Oaks.

Rose-Redwood, R. and D. Alderman (2011) Critical Interventions in Political Toponymy. ACME: An International E Journal for Critical Geographies 10.1-6, https://acme-journal.org/index.php/ acme/article/view/879.

Schneider, E. C. (2011) Smack. Heroin and the American City. University of Pennsylvania Press. Philadelphia.

Stuart, F. (2014) From 'Rabble Management' to 'Recovery Management': Policing Homelessness in Marginal Urban Space. Urban Studies 51.9, 1909-25.

Tissot, S. (2015) Good Neighbors: Gentrifying Diversity in Boston's South End [2011], London, Verso

White, W. L. (1998) Slaying the Dragon. The History of Addiction Treatment and Recovery in America. Chestnut Health System, Normal, Illinois.

\section{NOTES}

1. The misuse of opioids - be they legal (analgesic drugs) or illegal (heroin), obtained through legal channels (on prescription) or on the underground market - is estimated to affect almost 12 million people in the United States, with an estimated two million of them suffering from addictive disorders (Ahrnsbrak et al. 2017).

2. In Massachusetts, the overdose death rate more than doubled, topping the 2,000 deaths per year mark, between 2013 and 2016 (Massachusetts Department of Public Health, 2016).

3. Note for readers of the English translation: This article was written for a special issue of the journal EchoGeo, on toponymy. It is based on a field survey conducted between September 2018 and June 2019. Since then, the health crisis caused by the coronavirus pandemic has aggravated the situation in terms both of overdose mortality (with over 80,000 deaths nationwide in 2020) and of the issues and conflicts around the use of public space in the territory under study. According to local media, a coalition of residents from both neighbourhoods has created and is using a new toponymy, "Marty's Mile", to emphasize Mayor Marty Walsh's responsibility. As Walsh has been appointed Secretary of Labour in the Biden administration, the city council's actions might follow a new course. These new developments will be studied in future research.

4. With law enforcement professionals in police and justice departments, health and harm reduction workers, local elected officials, local residents, relatives of drug users and users' rights activists. 
5. Parents' meetings in schools, residents' associations, groups campaigning for drug users' rights, drug users' parents' discussion groups, the city council, the state harm reduction commission, and public neighbourhood meetings.

6. The gentrification of South End is still spreading towards Dudley/Nubian Square while the wealth inequalities between white and African-American households are incommensurable; an official report states that the average net worth of white households is $\$ 247,000$ while that of African-American households is $\$ 8$ (City of Boston, 2017).

7. In a quick survey of the local press (Boston Globe and Boston Herald) via the Factiva platform, we found 111 articles published since 2015 that included the expression Methadone Mile, while none used activists' preferred term Recovery Road (see above).

8. At the time of the survey, this project was under discussion.

9. A pun in which Ham is used in reference to "the pigs".

10. This photograph was sent to me by a respondent who is a professional in the field of addiction care in the neighbourhood. This sign was also mentioned in a blog post (Fitzgerald, 2017).

11. Recovery and healing expectations are different for consumers, doctors, and relatives (Meyers, 2016). This also points to the debate within the medical community about how to best support people with addiction disorders and care for them, with some professionals supporting abstinence and others advocating for harm reduction. Care centres in which abstinence is seen as a means and end of treatment are most often located away from communities. Harm reduction approaches, on the contrary, take care of patients where they are at, both in terms of the territory on which they live and of their consumption trajectory and the care objectives which they set for themselves.

12. None of the city's shelters offer accommodation for couples.

13. The scheme costs the City of Boston approximately $\$ 2$ million (between development and operating costs, including the employment of eight social workers on site).

14. In France, the first low-risk consumption rooms were created in 2016 as a pilot project.

15. And most prominently the Mayor of Boston, who made a show of his personal involvement on the subject, as a former alcoholic, and of the evolution of his point of view on consumption rooms following visits in several sites in Canada.

\section{ABSTRACTS}

This paper analyses the various toponyms of an open drug use scene in Boston, located at the interface of three neighbourhoods - Newmarket, Dudley-Roxbury, and South End, - with diverse uses and dynamics. The reactions and demands of the residents of these different neighbourhoods reveal the power dynamics in the urban space, the toponymic choices of which are the main focus of this analysis: Mass \& Cass refers to the urban, colonial and racial history of the city and prohibition; Methadone Mile brings to mind the stigmatization of users and places of care; Recovery Road expresses the emergence of new care and harm reduction practices at work in this sector. Entering this scene by way of these names helps to unravel the complexity of the opioid crisis currently underway in the USA, the political stakes involved, and the changes it is driving in drug policy. 
INDEX

Keywords: Boston, opioid, overdose, open drug scene, socio-spatial dynamics Subjects: Sur le Champ - Sur le Terrain

\section{AUTHOR}

\section{ELSA VIVANT}

Elsa Vivant, Elsa.vivant@univ-paris-est.fr, Latts - Gustave Eiffel University 